\title{
Activation of the Normal Human Skin Cells by a Portable Dielectric Barrier Discharge-Based Reaction-Discharge System of a Defined Gas Temperature
}

\author{
Anna Dzimitrowicz, et al. [full author details at the end of the article]
}

Received: 20 July 2019 / Accepted: 13 October 2019 / Published online: 22 October 2019

(c) The Author(s) 2019

\begin{abstract}
Skin injury leading to chronic wounds is of high interest due to the increasing number of patients suffering from this symptom. Proliferation, migration, and angiogenesis are key factors in the wound healing processes. For that reason, controlled promotion of these processes is required. In this work, we present the portable helium-dielectric barrier discharge (He-DBD)-based reaction-discharge system of controlled gas temperature for biological activities. To make this He-DBD-based reaction-discharge system safe for biological purposes, a multivariate optimization of the operating parameters was performed. To evaluate the effect of the He-DBD operating parameters on the rotational gas temperature $\mathrm{T}_{\text {rot }}(\mathrm{OH})$, a design of experiment followed by a Response Surface Methodology was applied. Based on the suggested statistical model, the optimal operating conditions under which the $\mathrm{T}_{\text {rot }}(\mathrm{OH})$ is less than $37^{\circ} \mathrm{C}(310 \mathrm{~K})$ were estimated. Then, the resulted model was validated in order to confirm its accuracy. After estimation the optical operating conditions of HeDBD operation, the spectroscopic characteristic of the He-DBD-based reaction-discharge system in relevance to the several optical temperatures in addition to electron number density has been carried out. Additionally, the qualitative and quantitative analyses of the reactive oxygen species and reactive nitrogen species were performed in order to investigate of reactions and processes running in the He-DBD-gaseous phase and in the He-DBD-treated liquid. Next, the developed portable He-DBD-based reaction-discharge system, working under the optimal operating conditions, was used to stimulate the wound healing process. It was found that a $30 \mathrm{~s} \mathrm{He-DBD}$ treatment significantly increased the proliferation, migration, and angiogenesis of keratinocytes (HaCaT) and fibroblasts (MSU-1.1) cell lines, as well as human skin microvascular endothelial cells (HSkMEC.2). Hence, the application of the cold atmospheric pressure plasma generated in this He-DBD-based reaction-discharge system might be an alternative therapy for patient suffering from chronic wounds.
\end{abstract}

Keywords Wound healing · Angiogenesis · Migration · Proliferation · Cold atmospheric pressure plasma
Abbreviations
BBD
Box-Behnken design

Anna Dzimitrowicz and Aleksandra Bielawska-Pohl have equally contributed to this work. 


$\begin{array}{ll}\text { CAPP } & \text { Cold atmospheric pressure plasma } \\ \text { DoE } & \text { Design of experiment } \\ \text { HaCaT } & \text { Keratinocytes } \\ \text { He-DBD } & \text { Helium-dielectric barrier discharge } \\ \text { HSkMEC.2 } & \text { Human skin microvascular endothelial cells } \\ \mathrm{n}_{\mathrm{e}} & \text { Electron number density } \\ \text { OES } & \text { Optical emission spectrometry } \\ \text { RNS } & \text { Reactive nitrogen species } \\ \text { ROS } & \text { Reactive oxygen species } \\ \text { RSD } & \text { Relative standard deviation } \\ \text { RSM } & \text { Response surface methodology } \\ \text { RWC } & \text { Relative wound closure } \\ \mathrm{T}_{\text {exc }} & \text { Excitation temperature } \\ \mathrm{T}_{\text {rot }} & \text { Rotational temperature } \\ \mathrm{T}_{\text {vib }} & \text { Vibrational temperature } \\ \mathrm{UV} & \text { Ultra-violet }\end{array}$

\section{Introduction}

Skin injury leading to chronic wounds is of high interest due to the increasing number of patients suffering from this symptom [1]. Generally, wounds, being the result of damage to the skin, are highly susceptible to pathogenic microorganisms [2]. Widespread wound infections occur after surgeries or the use of several medical instruments such as cannula, drips, and needles [3]. Giacometti et al, [3] suggested that Staphylococcus aureus, Pseudomonas aeruginosa, and Escherichia coli are the most common bacteria detected in the wounds. To inhibit bacterial growth, the most popular therapies are based on the application of antibiotics [4], which might lead to antibiotic resistance in the environment. In addition to killing microorganisms responsible for wound infections, there is also a high need to activate the normal skin cells in order to enhance the wound healing efficiency. For that reason, alternative wound healing therapies have been searched and extended. Very recently, special attention has been paid to the use of cold atmospheric pressure plasma (CAPP) in dermatology, thanks to the ability of these ionized-gas sources is to improve the wound healing process [5-18].

Over the past few years, the interest of the controlled applications of CAPPs has rapidly increased. They include not only the utilization of CAPPs in dermatology [5-18], but also application of CAPP in the synthesis of nanomaterials [19-21], the germination of seeds [22], inhibiting the proliferation of cancers cell lines [23, 24], and so on. This is possible because CAPP operation results in the generation of different reactive oxygen species (ROS, i.e., $\mathrm{O}_{3}, \mathrm{H}_{2} \mathrm{O}_{2}, \mathrm{O} \cdot \mathrm{O}_{2}^{-}, \mathrm{OH} \cdot$ ) and reactive nitrogen species (RNS, i.e., $\mathrm{NO}, \mathrm{NO}_{2}$ ), in addition to the emission of UV radiation and heat [7-9, 18, 25, 26].

The use of CAPPs in dermatology is related to their ability to inactivate pathogenic microorganisms as well as to enhance cell angiogenesis, to stimulate cell proliferation and migration, and to activate receptors on the cell surface. Angiogenesis, which is the formation of new blood vessels, is a major part of the wound healing process [27]. In order to increase cell motility, proliferation, and angiogenesis in wound healing without triggering the inflammation or apoptosis processes, the concentration of the above-mentioned reactive species needs to be tightly controlled [15]. For that reason, the effect of various CAPP treatments on skin cell 
lines such as fibroblasts [18, 28-30] and keratinocytes [18, 29-34] has been examined. These studies have established that CAPP-based devices are effective tools for stimulating the wound healing process [18, 29-36]. Interestingly, the type and amount of generated ROS and RNS, as well as the emitted UV radiation and heat, which facilitated the wound healing processes, were found to be highly dependent on the plasma source.

To date, a few reaction-discharge systems have been developed for further applications comprise medicine and dermatology. These reaction-discharge systems include dielectric barrier discharges (DBDs) [14, 15], corona discharges (CDs) [37], microwave-induced plasmas (MIPs) [11, 12], and plasma jets named kINPen [5, 7-10, 17] or COST [38, 39], in addition to the non-thermal atmospheric pressure plasma jets studied and utilized by e.g. Rad et al. [40], Gidon et al. [41, 42], Darmawati et al. [43], Cheng et al. [44], Busco et al. [45]. To be applied in biological systems, the reaction-discharge systems should provide a low gas temperature, i.e., less than $40{ }^{\circ} \mathrm{C}$, along with the controlled production of reactive chemical compounds such as ROS and RNS, and the emission of UV radiation [9].

Different computational models based on the Monte Carlo simulation, fluid dynamics (CFD), and 2D cylindrically symmetric hydrodynamics have been developed to better understand various properties (e.g. the effect of the supplied power, the temperature distribution, and the different species density distribution) of the kINPen plasma jet device [9]. Additionally, Gidon and co-workers [41] reported a predictive modelling approach for adequately describing the system dynamics of a He atmospheric pressure plasma jet using a model predictive control strategy [41].

The main aim of the present study was to develop a portable and efficient He-DBD-based reaction-discharge system of a controlled gas temperature for the selected biological activities, including the activation of normal human skin cell lines by stimulating their proliferation, migration, and angiogenesis. Compared to others studies of atmospheric pressure plasma jets [5, 7-10, 17, 38-45], the presented He-DBD-based reaction-discharge system is characterized by a unique in its class DBD generator that provides an ability to modulate either frequency or duty cycle, and it is cheaper and simpler compared to the classical dc or ac generators commercially used. The design of experiments (DOE) approach followed by the response surface methodology (RSM) were applied for the multivariate optimization of the operating conditions of the above mentioned system and the selection of settings under which a rotational temperature of the $\mathrm{OH}$ molecules $\left(\mathrm{T}_{\text {rot }}(\mathrm{OH})\right)$, reflecting the gas temperature $\left(\mathrm{T}_{\mathrm{g}}\right)$ of the HeDBD plasma, was less than $37{ }^{\circ} \mathrm{C}(310 \mathrm{~K})$. Additionally, the selected spectroscopic parameters, i.e., the excitation $\left(\mathrm{T}_{\mathrm{exc}}\right)$, vibrational $\left(\mathrm{T}_{\mathrm{vib}}\right)$, and rotational $\left(\mathrm{T}_{\text {rot }}\right)$ temperatures, and the electron number density $\left(\mathrm{n}_{\mathrm{e}}\right)$, of the He-DBD were determined when the developed reactiondischarge system was working under optimal operating conditions. Optical emission spectrometry (OES) was used to identify the type of ROS and RNS produced in the gaseous phase of He-DBD under defined operating conditions. The concentrations of the selected ROS and RNS in the liquid phase treated by He-DBD were assessed using spectrophotometric methods. Finally, the effect of the He-DBD plasma generated under the optimal operating conditions were assessed on the proliferation, migration, and angiogenesis of the skin cell lines keratinocytes (HaCaT) and fibroblasts (MSU-1.1), and on human skin microvascular endothelial cells (HSkMEC.2). 


\section{Experimental Procedures}

\section{Construction of the Portable He-DBD-Based Reaction-Discharge System}

In order to provide a better wound healing efficiency according to the proliferation, migration, and angiogenesis of the normal skin cell lines, the portable He-DBD-based reaction discharge system was developed and optimized. As shown in Fig. 1, the main part of this system was a reaction-discharge head, made of an E-57 epoxy resin, containing a quartz tube (ID $=10 \mathrm{~mm}$ ) onto which two ring-like tungsten electrodes (ID $=2.0 \mathrm{~mm}$ ) were mounted. The above-mentioned parts were covered with a CORIAN ${ }^{\circledR}$ insulator and inserted into a ceramic tube. The edge of the quartz tube was $15 \mathrm{~mm}$ below the edge of the ceramic tube. Stable-in-time and homogenous glow He-DBD was sustained in the quartz tube by supplying a high voltage (HV) potential up to $15 \mathrm{kV}$ to both electrodes from a pulse modulated alternating current $(40 \mathrm{kHz})$ power generator (Dora Electronics Equipment, Poland). Helium 6.0 (99.9999\%, Linde, Poland) was used as the discharge gas due to its high thermal conductivity of $190.6 \times 10^{-3} \mathrm{~W} \mathrm{~m}^{-1} \mathrm{~K}^{-1}$ at $400 \mathrm{~K}$. The voltage was modulated with a square wave at frequencies changing from 2.1 to $2.8 \mathrm{kHz}$ and with the duty cycles changing from 25 to $75 \%$. The actual discharge currents were measured using a Rogowski coil

Fig. 1 A schematic representation of the portable He-DBDbased reaction-discharge system

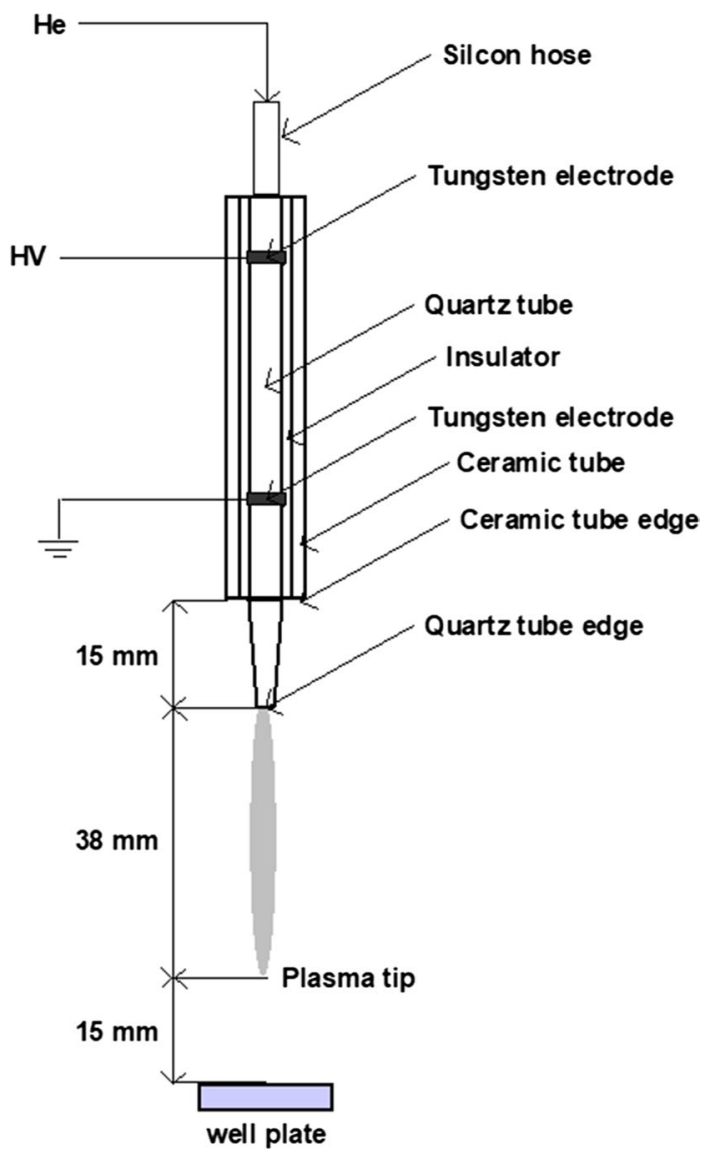


current probe (Dora Electronics Equipment, Poland), while a HV probe (1:1000), built-in in the power generator, was applied for the voltage measurements. Finally, the discharge current and the voltage signals were processed by a two-channel $60 \mathrm{MHz}$ SDS1104X oscilloscope (Siglent, China). To control the flow rate of He within 4.0-11.0 L min ${ }^{-1}$, a $1355 \mathrm{G}$ Sho-Rate low flow glass tube flowmeter (Brooks Instruments, USA) was used.

\section{Response Surface Methodology: The Optimization of the Portable He-DBD-Based Reaction-Discharge System}

Since the portable He-DBD-based reaction-discharge system was planned to treat the normal human skin cells, its $\mathrm{T}_{\mathrm{g}}$ should be less than $37{ }^{\circ} \mathrm{C}(310 \mathrm{~K})$. Hence, it was necessary to optimize the operating parameters of the DBD-based reaction-discharge system to gain such a $T_{g}$ value. Accordingly, the RSM was used to model the $T_{g}$ of the system versus the selected operating parameters and to find on the basis of the established response surface regression model the optimal settings that could provide the desired $\mathrm{T}_{\mathrm{g}}$ value. To have insight into the kinetic energy of the gaseous phase of the He-DBD, the $\mathrm{T}_{\text {rot }}(\mathrm{OH})$, as determined based on the emission spectra of He-DBD, was used to accurately estimate the $\mathrm{T}_{\mathrm{g}}$ $[46,47]$. A Box-Behnken experimental design (BBD) was used to model the system versus the following operating parameters: A-the frequency used to modulate the sinusoidal voltage (in $\mathrm{kHz}$ ), $\mathrm{B}$ - the duty cycle (in \%), and $\mathrm{C}$ - the $\mathrm{He}$ flow rate (in $\mathrm{L} \mathrm{min}^{-1}$ ). The RSM experimental design comprised 15 randomized runs at the 3 different levels of operating parameters and included the 3 central points. The levels of the operating parameters were selected based on the observations of the stable operation of homogenous He-DBD and were as follows: $\mathrm{A}-2.10,2.45$, and $2.80 \mathrm{kHz}$; $\mathrm{B}-25 \%, 50 \%$, and $75 \%$; and $\mathrm{C}-4.0$, 7.5, and $11.0 \mathrm{~L} \mathrm{~min}^{-1}$. All runs were carried out in one block according to the run order given in Table 1.

To reproduce the variability in the system, the response of the system was modeled with a complete quadratic function, including the main linear and quadratic effects of the operating parameters on the $\mathrm{T}_{\text {rot }}(\mathrm{OH})$, and their two-way interactions [48]. In addition, to reduce the dimensionality of the final response surface model, the insignificant terms were eliminated using a stepwise-selection-of-terms algorithm [48]. In this case, the terms were added during the selection procedure to maintain a hierarchical model of the system. The suitability of the established model was assessed using the ANOVA test and the established $p$-values for each source and the determination coefficient for the whole response surface regression model $\left(\mathrm{R}^{2}\right)$. The model was also tested for the lack-of-fit that provided the evidence of its adequacy and efficacy [48]. Finally, the quality of the model and its reliability were checked by examining the residuals. In this case, the normal probability plot and a scatterplot of the residuals versus the run order were looked through for any heteroscedasticity.

\section{Determination of the Optical Temperatures and the Electron Number Density}

The emission spectra of He-DBD were acquired to characterize the developed and studied CAPP source. Radiation emitted by the He-DBD was observed in the range from 200 to $900 \mathrm{~nm}$, alongside the plasma tip. It was directly collimated using a UV quartz lens on the entrance slit of a Shamrock SR500i high-resolution imaging spectrograph (Andor, UK), equipped with two holographic gratings (1800 and 1200 lines $\mathrm{mm}^{-1}$ ) and a CCD camera $(1024 \times 255$ pixels, Andor, UK). The acquisition time was $10 \mathrm{~s}$. Such an observation layout 
Table 1 The Box-Behnken experimental design with the actual and coded (in brackets) values of the operating conditions of the He-DBD-based reaction-discharge system along with the standard and run orders and the values of the response

\begin{tabular}{lllllll}
\hline Standard order & Run order & $\begin{array}{l}\text { A-frequency } \\
\text { of modulation, } \\
\mathrm{kHz}\end{array}$ & $\begin{array}{l}\mathrm{B} \text {-duty cycle, } \\
\%\end{array}$ & $\begin{array}{l}\mathrm{C}-\text { flow rate, } \\
\mathrm{L} \mathrm{min}\end{array}$ & $\mathrm{T}_{\text {rot }}(\mathrm{OH}),{ }^{\circ} \mathrm{C}$ & $\mathrm{T}_{\text {rot }}(\mathrm{OH}), \mathrm{K}$ \\
\hline 15 & 1 & $2.45(0)$ & $50(0)$ & $7.5(0)$ & 287 & 560 \\
2 & 2 & $2.80(+1)$ & $25(-1)$ & $7.5(0)$ & 191 & 464 \\
12 & 3 & $2.45(0)$ & $75(+1)$ & $11.0(+1)$ & 133 & 406 \\
11 & 4 & $2.45(0)$ & $25(-1)$ & $11.0(+1)$ & 101 & 374 \\
7 & 5 & $2.10(-1)$ & $50(0)$ & $11.0(+1)$ & 74 & 347 \\
3 & 6 & $2.10(-1)$ & $75(+1)$ & $7.5(0)$ & 115 & 388 \\
5 & 7 & $2.10(-1)$ & $50(0)$ & $4.0(-1)$ & 132 & 405 \\
1 & 8 & $2.10(-1)$ & $25(-1)$ & $7.5(0)$ & 168 & 441 \\
9 & 9 & $2.45(0)$ & $25(-1)$ & $4.0(-1)$ & 131 & 404 \\
14 & 10 & $2.45(0)$ & $50(0)$ & $7.5(0)$ & 142 & 415 \\
10 & 11 & $2.45(0)$ & $75(+1)$ & $4.0(-1)$ & 580 & 853 \\
13 & 12 & $2.45(0)$ & $50(0)$ & $7.5(0)$ & 180 & 453 \\
4 & 13 & $2.80(+1)$ & $75(+1)$ & $7.5(0)$ & 174 & 447 \\
8 & 14 & $2.80(+1)$ & $50(0)$ & $11.0(+1)$ & 180 & 453 \\
6 & 15 & $2.80(+1)$ & $50(0)$ & $4.0(-1)$ & 224 & 497 \\
\hline
\end{tabular}

$\mathrm{T}_{\text {rot }}(\mathrm{OH})$ : rotational temperature of the $\mathrm{OH}$ molecules; A: frequency of modulation; $\mathrm{B}$ : duty cycle; $\mathrm{C}$ : He flow rate

was reasonable because of the application of the He-DBD plasma tip in the vertical position for the wound healing. All the emission spectra of the He-DBD system were acquired under the operating conditions given in more details in Table 1 [each parameter setting is defined, including the frequency of modulation (in $\mathrm{kHz}$ ), the duty cycle (in \%), the $\mathrm{He}$ flow rate (in $\left.\mathrm{L} \mathrm{min}^{-1}\right)$ ]. The unresolved emission spectra of the $\mathrm{OH}$ molecule in the range of 300-320 nm, belonging to the $\mathrm{OH}(\mathrm{A}-\mathrm{X})$ system, the (0-0) vibrational-rotational transition with the band head at $308.9 \mathrm{~nm}$, was chosen for the determination of the $\mathrm{T}_{\text {rot }}(\mathrm{OH})$. Similar procedure was also applied in the case of $\mathrm{T}_{\text {rot }}\left(\mathrm{N}_{2}\right)$ and the $(0-2)$ band of $\mathrm{N}_{2}(\mathrm{C}-\mathrm{B})$ with the bandhead at $380.2 \mathrm{~nm}$ was selected for that purpose. The emission spectra of $\mathrm{N}_{2}$ were collected in the range within $376-380 \mathrm{~nm}$. The $\mathrm{T}_{\text {rot }}(\mathrm{OH})$ and $\mathrm{T}_{\text {rot }}\left(\mathrm{N}_{2}\right)$ values were determined by fitting the recorded $\mathrm{OH}(\mathrm{A}-\mathrm{X})$ and $\mathrm{N}_{2}(\mathrm{C}-\mathrm{B})$ emission spectra with the spectra simulated at various temperatures using the Lifbase software (2.2 version, SRI International, USA) and Specair (2.1 version, Spectrafit, France), respectively. This temperature was assumed to be a very good estimator of the $T_{g}$ of He-DBD. In addition, other optical temperatures such as the $\mathrm{T}_{\text {exc }}$, the $\mathrm{T}_{\mathrm{vib}}$, and the $\mathrm{T}_{\text {rot }}$, and the $\mathrm{n}_{\mathrm{e}}$ were assessed for He-DBD operated under the optimal conditions. The $\mathrm{T}_{\text {exc }}$ of $\mathrm{H}$ atoms was determined using the twoline method, using $656.20 \mathrm{~nm}\left(\mathrm{H}_{\alpha}\right.$ line $)$ and $486.13 \mathrm{~nm}\left(\mathrm{H}_{\beta}\right.$ line $)$ emission lines [49].The $\mathrm{T}_{\text {vib }}$ of the $\mathrm{OH}$ molecules was evaluated based on two $\mathrm{OH}(\mathrm{A}-\mathrm{X})$ molecular bands, i.e., the (1-0) and (0-0) transitions. In turn, experimentally measured $\mathrm{OH}$ molecular bands in the range within $280-320 \mathrm{~nm}$ were fitted with those simulated using the Lifbase software at different values of the $T_{\text {vib }}$ [50]. A similar procedure was also applied to determine the $T_{\text {rot }}$ 
of the $\mathrm{N}_{2}^{+}$molecules. In this case, the emission spectra of the $\mathrm{N}_{2}^{+}(\mathrm{B}-\mathrm{X})$ system, the $(0-0)$ transition with the band head at $391.4 \mathrm{~nm}$, were simulated in the range of 388-392 nm at various values of the $T_{\text {rot }}$. Then, these simulated emission spectra were compared with the experimental data. The precision (expressed as the relative standard deviation, RSD) of the temperature measurements was better than $10 \%$. The $n_{e}$ was determined on the basis of the Stark broadening $\left(\Delta \lambda_{\mathrm{S}}\right)$ of the $\mathrm{H}_{\beta}$ line at $486.13 \mathrm{~nm}$, using the formula given by Gigosos et al., i.e., $\left(\Delta \lambda_{\mathrm{S}} / 4.800\right)=\left(\mathrm{n}_{\mathrm{e}} / 10^{17}\right)^{0.68116}$ [50]. The experimentally measured profiles of the $\mathrm{H}_{\beta}$ line were fitted using the Voight algorithm. Only the Lorentz part $\left(\Delta \lambda_{\mathrm{L}}\right)$ of the Voight algorithm was applied to calculate the $\Delta \lambda_{S}$. Additionally, the Van der Walls broadening $\left(\Delta \lambda_{\mathrm{vdW}}\right)$ of the $\mathrm{H}_{\beta}$ line profile was also used in the final calculations of the $\Delta \lambda_{\mathrm{S}}$, i.e., $\Delta \lambda_{\mathrm{S}}=\Delta \lambda_{\mathrm{L}}-\Delta \lambda_{\mathrm{vdW}}$.

\section{Elucidation of the Reactions and Processes Running in the Gaseous Phase of He-DBD and the Liquid Phase Treated by He-DBD}

Several experimental techniques were applied to reveal the possible reactions and processes occurring in the gaseous phase of the He-DBD plasma as well as in the liquid treated by this plasma. These analyses were undertaken when the He-DBD-based reaction-discharge system was operated under optimal conditions, found on the basis of the validated response surface regression model.

Accordingly, the ROS and RNS produced in the gaseous phase of He-DBD were identified on the basis of its emission spectra measured with OES. These spectra were recorded from the same plasma region within 200-900 nm, using the same instrument as was described in the "Determination of the Optical Temperatures and the Electron Number Density" section.

The spectrophotometric methods were used for the quantitative determination of the selected ROS and RNS, i.e., hydrogen peroxide $\left(\mathrm{H}_{2} \mathrm{O}_{2}\right)$, and nitrite ions $\left(\mathrm{NO}_{2}^{-}\right)$, produced in a physiological saline solution $(0.85 \% \mathrm{~m} / \mathrm{v} \mathrm{NaCl})$ treated by He-DBD, which was operated under the optimal operating conditions, i.e. the He flow rate of $10.6 \mathrm{~L} \mathrm{~min}^{-1}$, the frequency of modulation of $2.1 \mathrm{kHz}$, and the duty cycle of $74 \%$. The glass vials were put onto the magnetic stirring and vigorously mixed during the treatment. The distance between the tip of the He-DBD plasma and the surface of the treated liquid was $15 \mathrm{~mm}$.

The concentration of $\mathrm{H}_{2} \mathrm{O}_{2}$ was measured based on the production of the peroxovanadium cation $\left(\mathrm{VO}_{3}^{2+}\right)$ [49]. The above-mentioned orange $\mathrm{VO}_{3}^{2+}$ cation, showing a maximum absorbance at $450 \mathrm{~nm}$, was obtained as a result of the reaction between the $\mathrm{H}_{2} \mathrm{O}_{2}$ molecules with ammonium metavanadate $\left(\mathrm{NH}_{4} \mathrm{VO}_{3}\right)$ in the medium of $0.58 \mathrm{~mol} \mathrm{~L}-1 \mathrm{H}_{2} \mathrm{SO}_{4}$. Hence, $2.5 \mathrm{~mL}$ of the $0.85 \%(\mathrm{~m} / \mathrm{v}) \mathrm{NaCl}$ solution (Sigma-Aldrich, Germany), treated for 300,600 , or 1200 s by He-DBD, were mixed with $2.50 \mathrm{~mL}$ of the $\mathrm{NH}_{4} \mathrm{NO}_{3} / \mathrm{H}_{2} \mathrm{SO}_{4}$ stock solution, and diluted to $25.0 \mathrm{~mL}$ using re-distilled water. The suggested plasma treatment time was chosen to provide the best accuracy in these types of measurements. The concentrations of $\mathrm{NH}_{4} \mathrm{VO}_{3}$ (Avantor Performance Materials, Poland) and $\mathrm{H}_{2} \mathrm{SO}_{4}$ (Avantor Performance Materials, Poland) in the above-mentioned stock solution were $6.2 \mathrm{mmol} \mathrm{L}^{-1}$ and $0.058 \mathrm{~mol} \mathrm{~L}^{-1}$, respectively. The concentration of $\mathrm{H}_{2} \mathrm{O}_{2}$ in the analyzed samples was calculated based on the absorbance value, recorded at $450 \mathrm{~nm}$ using a double-beam UV/Vis spectrophotometer (Specord 210 Plus, Analityk Jena, Germany). The spectrophotometer was zeroed using a respective procedural blank sample.

The concentration of $\mathrm{NO}_{2}^{-}$was determined using the Rivanol method [51, 52]. In this method, a red-purple diazonium salt, showing a maximum absorbance at $595 \mathrm{~nm}$, was 
produced as the product of the reaction between Rivanol (2-ethoxy-6,9-diamino-acridinium lactate, $\mathrm{C}_{18} \mathrm{H}_{21} \mathrm{~N}_{3} \mathrm{O}_{4}$ ) and the $\mathrm{NO}_{2}^{-}$ions. To determine the $\mathrm{NO}_{2}^{-}$concentration in the analyzed samples, $5.0 \mathrm{~mL}$ of the $0.85 \%(\mathrm{~m} / \mathrm{v}) \mathrm{NaCl}$ solution, treated for 300,600 , or $1200 \mathrm{~s}$ by He-DBD, were mixed with $1.25 \mathrm{~mL}$ of a $0.1 \%$ Rivanol solution (Prolab, Poland), acidified with $0.1 \mathrm{~mol} \mathrm{~L}^{-1} \mathrm{HCl}$ (Avantor Performance Materials, Poland), and topped with redistilled water to $10 \mathrm{~mL}$. The suggested plasma treatment time was chosen to provide the best accuracy in these types of measurements. The concentration of the $\mathrm{NO}_{2}^{-}$ions in the analyzed samples was calculated based on the absorbance, recorded at $595 \mathrm{~nm}$ using a double-beam UV/Vis spectrophotometer (Specord 210 Plus, Analityk Jena, Germany). The spectrophotometer was zeroed using a respective procedural blank sample.

The $\mathrm{pH}$ (the total concentration of the $\mathrm{H}_{3} \mathrm{O}^{+}$ions) of the $0.85 \%(\mathrm{~m} / \mathrm{v}) \mathrm{NaCl}$ solution was estimated using a CPC-505 pH meter (Elmetron, Poland) before and immediately after their 300, 600-, and 1200-s treatments with He-DBD.

\section{Cells and Culture Conditions}

The HaCaT cell line coming from the spontaneously immortalized human keratinocytes [53] was used to test the effect of the He-DBD plasma on biological activity in reference to the proliferation, migration, and angiogenesis of normal human cells. In addition, the MSU-1.1 cell line, obtained by the v-myc oncogene transformation of the foreskin fibroblasts [54] was used as representative of dermal skin cells. Finally, the human microvascular endothelial skin cell line, HSkMEC.2 [55], was used for the study of pseudotubes formation. The cell lines were cultured at $37{ }^{\circ} \mathrm{C}$ in an incubator under the $5 \% \mathrm{CO}_{2}$ and $95 \%$ air atmosphere. The cells were maintained in Opti-MEM with GlutaMAX (Thermo Fisher Scientific Inc., USA) medium supplemented with 3\% fetal bovine serum (FBS, Gibco, $\mathrm{UK}), 100 \mathrm{U} \mathrm{mL}^{-1}$ penicillin and $100 \mathrm{~g} \mathrm{~mL}^{-1}$ streptomycin (Sigma-Aldrich, Germany). They were routinely passaged using a $0.05 \%$ trypsin/0.02\% EDTA (w/v) solution.

\section{He-DBD-Based Treatment of Human Skin Cell Lines}

The human skin cell lines HaCaT, MSU-1.1, and HSkMEC. 2 were detached and suspended in $0.85 \%(\mathrm{~m} / \mathrm{v}) \mathrm{NaCl}$ to a final concentration of $1 \times 10^{6}$ cells $\mathrm{mL}^{-1}$, and treated with the HeDBD plasma operated under the optimal conditions, however, maintaining a $15 \mathrm{~mm}$ distance between the tip of the He-DBD plasma and the treated biological materials, i.e., cells that were suspended in an Eppendorf tube. The normal human cells were treated with the He-DBD plasma for a defined time, i.e., from $0 \mathrm{~s}$ (control), 10, 30, 60, 90, 180, 270, and $360 \mathrm{~s}$, and then seeded onto the 96-flat bottom well plates in triplicates. After treatment cells were suspended in culture medium and used in the following in vitro experiments.

\section{Proliferation Assay}

The cell proliferation was investigated using the standard MTT test (Sigma-Aldrich, Germany). Briefly, $2 \times 10^{3}$ cells were treated with He-DBD for a defined time (0-360 s) and then seeded onto the 96-flat bottom well plates in triplicates [56]. The test was carried out for up to 7 days. It was unequivocally evidenced in this test that the cells treated longer than $90 \mathrm{~s}$ stopped proliferating and their apoptosis was observed. 


\section{Wound Healing Assay}

For the scratch wound assay He-DBD-treated cell lines HSkMEC.2, HaCaT, and MSU1.1 were cultured separately in 48 -well plates in medium supplemented with serum and used in the experiments after the cells reached $100 \%$ of confluence. Next, scratches lines were made with $200 \mu \mathrm{L}$ tips. PBS was then used to wash cells three times and cells scratched out were removed. The remaining adherent cells were cultured with serumfree medium in an incubator with $5 \% \mathrm{CO}_{2}$ at $37{ }^{\circ} \mathrm{C}$. Pictures were collected at $0,16,24$, 48,72 , and $84 \mathrm{~h}$, and photographed under an inverted light microscope to measure the scratch distance. The closure area was calculated using ImageJ software and presented as relative wound closure (RWC, \%) as previously described [57].

\section{Angiogenic Assay}

The angiogenic properties of the HSkMEC.2 cells treated with He-DBD for the defined time were evaluated by seeding the cells on the surface of growth factor reducedMatrigel matrix (Corning, USA) and examined by following the formation of pseudovessels. The endothelial cells $\left(1.5 \times 10^{4}\right.$ cells/well $)$ were seeded in duplicates on the Matrigel-coated 96-well plates and cultured in the standard conditions for up to $24 \mathrm{~h}$. Photographs were taken after $6 \mathrm{~h}$ of culture. Angiogenesis was evaluated by several parameters: the mean mesh size, the number of nodes, and the total tube length. The results were calculated using the ImageJ Angiogenesis Analyzer Software (version 1.520 ) and presented as mean \pm SD.

In all in vitro tests all the graphs as well as statistical analysis were prepared using GraphPad Prism software (version 7.04, license number 885438).

\section{Results and Discussion}

\section{Optimization of the Portable He-DBD-Based Reaction Discharge System}

A Box-Behnken experimental design followed by the RSM was used to model the response, i.e., the $\mathrm{T}_{\mathrm{g}}$, being estimated by the $\mathrm{T}_{\text {rot }}(\mathrm{OH})$, of the He-DBD system versus selected operating parameters and find such optimal settings that could provide the $\mathrm{T}_{\mathrm{g}}$ of $37{ }^{\circ} \mathrm{C}(310 \mathrm{~K})$. To establish the response surface model, the He-DBD-based reaction-discharge system was run at different operating conditions (as given in Table 1 for a certain run) and the emission spectra of the He-DBD plasma were acquired to determine the $\mathrm{T}_{\mathrm{rot}}(\mathrm{OH})$. At the beginning, it was verified that the variability in the mean response for all 15 runs was higher than the variability of the repeated measurements of the response for each run. In addition, neither correlation nor trend was observed in the scatter plot of the response versus the run order. Therefore, it was concluded that the variability in the response was due to the changes of the operating parameters within the arbitrarily selected ranges. In this way, it was not necessary to stabilize the variance in the response through its transformation [47, 58].

To establish the response surface model, the $\mathrm{T}_{\text {rot }}(\mathrm{OH})$ values were fitted with a full quadratic polynomial response surface model. The equation of this model was as follows: $\mathrm{T}_{\text {rot }}(\mathrm{OH})\left[{ }^{\circ} \mathrm{C}\right]=-500.0+11.7 \times \mathrm{A}+11.0 \times \mathrm{B}+38.8 \times \mathrm{C}-0.1 \times \mathrm{A}^{2}-1.2 \times \mathrm{BC}$. It should be 
Table 2 The outcomes of the ANOVA and lack-of-fit tests for the response surface model found with the aid of the stepwise-selection-of-terms algorithm $(\alpha=0.25)$ for the He-DBD-based reaction-discharge system

\begin{tabular}{lclccc}
\hline Source & DF & Adjusted SS & Adjusted MS & F-value $^{\mathrm{a}}$ & $p$ value $^{\mathrm{b}}$ \\
\hline Model & 5 & 131,972 & 26,394 & 3.34 & 0.056 \\
Linear & 3 & 73,006 & 24,335 & 3.08 & 0.083 \\
A & 1 & 9841 & 9841 & 1.25 & 0.293 \\
B & 1 & 21,220 & 21,220 & 2.69 & 0.136 \\
C & 1 & 41,945 & 41,945 & 5.31 & 0.047 \\
Square & 1 & 15,580 & 15,580 & 1.97 & 0.194 \\
A & 1 & 15,580 & 15,580 & 1.97 & 0.194 \\
2-way interactions & 1 & 43,386 & 43,386 & 5.49 & 0.044 \\
BC & 1 & 43,386 & 43,386 & 5.49 & 0.044 \\
Error & 9 & 71,108 & 7901 & & 0.454 \\
Lack-of-fit & 7 & 59,803 & 8543 & 1.51 & \\
Pure error & 2 & 11,305 & 5653 & & \\
Total & 14 & 203,080 & & & \\
\hline
\end{tabular}

$D F$ degree of freedom, $S S$ sum of squares, $M S$ mean of squares, $A$ frequency of modulation (in $\mathrm{kHz}$ ), $B$ duty cycle (in \%), $C$ He flow rate (in $\mathrm{L} \mathrm{min}^{-1}$ )

${ }^{\text {a }}$ The $F$-test value for comparison of model variance with residual variance

${ }^{\mathrm{b}}$ The probability value for a given source in the model

noted, that frequency of modulation (A) in model was coded, i.e., values of frequency: $2.10,2.45$, and $2.80 \mathrm{kHz}$ correspond to respective values: $25 \%, 50 \%$ and $75 \%$ in model. The accuracy of this model was tested by the ANOVA and lack-of-fit tests. The results of both tests at $\alpha$ to enter equal of 0.25 [47] are given in Table 2 .

As can be seen, the response surface model was statistically significant $(p=0.056)$ and the following linear, square and 2-way interaction terms were significant, i.e., $\mathrm{B}(p=0.136)$, $\mathrm{C}(p=0.047), \mathrm{A}^{2}(p=0.194)$, and BC $(p=0.044)$, which all were lower than $\alpha=0.25$. The statistically insignificant term A $(p=0.293>0.25)$ was included in the model, considering the hierarchy of the terms. The $\mathrm{R}^{2}$ was relatively high $(65 \%)$, indicating that the gathered responses were well fitted with the model. In addition, the lack-of-fit test was statistically insignificant $(p=0.454>0.25)$, showing that there was no reason to reject the model nor evidence that it did not fit the experimental data well. This goodness-of-fit was also proved by the distribution of residuals. The normal probability plot showed that the values of the residuals were approximately normally distributed. A random pattern of the residuals was observed in their scatterplot versus the run order; they were uniformly distributed on both sides of the zero axis, except for one outlier (the observation no. 11 with the highest $\mathrm{T}_{\text {rot }}(\mathrm{OH})$ value of $580{ }^{\circ} \mathrm{C},(853 \mathrm{~K})$. Both scatterplots additionally confirmed that the response surface model was correct and well fitted the experimental values of the $\mathrm{T}_{\text {rot }}(\mathrm{OH})$ of the studied He-DBD reaction-discharge system.

Hence, the model was used to find the operating parameters of the He-DBD plasma so that its $\mathrm{T}_{\text {rot }}(\mathrm{OH}) \cong \mathrm{T}_{\mathrm{g}}$ was $37{ }^{\circ} \mathrm{C}(310 \mathrm{~K})$. It was established that the target value could be attained with the desirability of 0.999 when operating He-DBD at a frequency of modulation of $2.14 \mathrm{kHz}$, a duty cycle of $74 \%$, and a He flow rate of $10.6 \mathrm{~L} \mathrm{~min}^{-1}$. Using the above-mentioned settings, the $\mathrm{T}_{\text {rot }}(\mathrm{OH})$ value fitted with the model was less than $37{ }^{\circ} \mathrm{C}$ $(310 \mathrm{~K})$. To confirm the correctness of this selection of these operating conditions, the 
emission spectra of He-DBD, as operated at the above-mentioned operating parameters, were acquired and the $\mathrm{T}_{\text {rot }}(\mathrm{OH})$ was evaluated. It was just $37 \pm 10{ }^{\circ} \mathrm{C}(310 \pm 10 \mathrm{~K})$. This measure confirmed the usefulness of the RSM approach to quickly and reliably established the operating conditions of the He-DBD-based reaction-discharge system to operate it at the $\mathrm{T}_{\mathrm{g}}$ of $37{ }^{\circ} \mathrm{C}(310 \mathrm{~K})$. The selected operating parameters, based on the established response surface model, were used to operate the system in all further experiments.

\section{Spectroscopic Characteristic of the Developed He-DBD-Based Reaction-Discharge System}

In order to describe the investigated here He-DBD plasma source, the optical temperatures, i.e., the $\mathrm{T}_{\text {exc }}$, the $\mathrm{T}_{\mathrm{vib}}$, and the $\mathrm{T}_{\text {rot }}$ as well as the $\mathrm{n}_{\mathrm{e}}$, were additionally assessed. The evaluated spectroscopic parameters of He-DBD, working under the optimal operating conditions, were shown in Table 3. As can been seen, the $\mathrm{T}_{\text {exc }}(\sim 3300 \mathrm{~K})$ was comparable with the $\mathrm{T}_{\text {vib }}(\sim 3000 \mathrm{~K})$ and was much higher than the $\mathrm{T}_{\text {rot }}$. It was also observed that the $\mathrm{T}_{\text {rot }}\left(\mathrm{N}_{2}^{+}\right)$ was about twice higher than the $\mathrm{T}_{\text {rot }}(\mathrm{OH})$ and the $\mathrm{T}_{\text {rot }}\left(\mathrm{N}_{2}\right)$. Probably, the excited states of the $\mathrm{N}_{2}^{+}$molecules, i.e., $\mathrm{N}_{2}^{+}(\mathrm{B})$, were produced by the interaction of ground state $\mathrm{N}_{2}$ molecules $\left(\mathrm{N}_{2}(\mathrm{X})\right)$ with the metastable states of the He atoms $\left(\mathrm{He}^{\mathrm{m}}\right)$, i.e., $\mathrm{He}\left({ }^{3} \mathrm{~S}\right)$ and/or $\mathrm{He}$ $\left({ }^{1} \mathrm{~S}\right)$, as a result of the Penning ionization process, i.e., $\mathrm{N}_{2}(\mathrm{X})+\mathrm{He}^{\mathrm{m}}=\mathrm{N}_{2}^{+}(\mathrm{B})+\mathrm{He}+\mathrm{e}^{-}[59]$. The threshold energies of the $\mathrm{He}\left({ }^{3} \mathrm{~S}\right)$ and $\mathrm{He}\left({ }^{1} \mathrm{~S}\right)$ states $(19.8$ and $20.9 \mathrm{eV}$, respectively) are much higher than the ionization-excitation energy of the $\mathrm{N}_{2}^{+}(\mathrm{B})$ state, i.e., $18.7 \mathrm{eV}$, and thus the additional energy from the He metastable states are converted to the rotational energy of the $\mathrm{N}_{2}^{+}$molecules during the Penning ionization process. It should be noticed that the $\mathrm{T}_{\text {rot }}(\mathrm{OH})$ was equilibrated to the $\mathrm{T}_{\text {rot }}\left(\mathrm{N}_{2}\right)$, i.e., $\mathrm{T}_{\text {rot }}(\mathrm{OH}) \approx \mathrm{T}_{\text {rot }}\left(\mathrm{N}_{2}\right)$, and hence close to the $\mathrm{T}_{\mathrm{g}}$ of He-DBD, likely due to an increase in the frequency of the molecule collisions in the developed CAPP source [60]. The determined values of the $\mathrm{T}_{\text {rot }}$ of the $\mathrm{N}_{2}^{+}$and $\mathrm{OH}$ molecules were consistent with those reported in previous works related to various DBDs jets generated in the $\mathrm{He}$ atmosphere $[59,61]$. Finally, the relations between the determined optical temperatures were as follows: $\mathrm{T}_{\text {exc }} \approx \mathrm{T}_{\mathrm{vib}} \gg \mathrm{T}_{\text {rot }}\left(\mathrm{N}_{2}^{+}\right)>\mathrm{T}_{\text {rot }}(\mathrm{OH}) \approx \mathrm{T}_{\text {rot }}\left(\mathrm{N}_{2}\right)$, indicating that developed He-DBD was far from the thermodynamic equilibrium. The $\mathrm{n}_{\mathrm{e}}$ determined for He-DBD was estimated to be $\sim 1.5 \times 10^{14} \mathrm{~cm}^{-3}$.

\section{Identification of the Reactive Species in the Gaseous Phase of He-DBD and in the Liquid Phase Treated by the Plasma}

Before the quantitative determination of the selected ROS and RNS in the liquid phase treated by He-DBD operated under the optimal conditions, initially, the emission spectrum of the plasma was acquired and analyzed to identify the possible reactive species in the gaseous phase of He-DBD (Fig. 2). As displayed in Fig. 2, the $\mathrm{N}_{2}, \mathrm{~N}_{2}^{+}, \mathrm{NH}, \mathrm{NO}$, and $\mathrm{OH}$ species were easily excited in He-DBD. Its emission spectrum was dominated by the

Table 3 The spectroscopic parameters determined for the He-DBD plasma operated under the optimal operating conditions in the developed reaction-discharge system

\begin{tabular}{lllllll}
\hline CAPP source & $\mathrm{T}_{\text {exc }}(\mathrm{H}), \mathrm{K}$ & $\mathrm{T}_{\mathrm{vib}}(\mathrm{OH}), \mathrm{K}$ & $\mathrm{T}_{\text {rot }}\left(\mathrm{N}_{2}^{+}\right), \mathrm{K}$ & $\mathrm{T}_{\text {rot }}(\mathrm{OH}), \mathrm{K}$ & $\mathrm{T}_{\text {rot }}\left(\mathrm{N}_{2}\right), \mathrm{K}$ & $\mathrm{n}_{\mathrm{e}}, \mathrm{cm}^{-3}$ \\
\hline He-DBD & $3300 \pm 300$ & $3000 \pm 200$ & $600 \pm 50$ & $310 \pm 10$ & $320 \pm 15$ & $\sim 1.5 \times 10^{14}$ \\
\hline
\end{tabular}




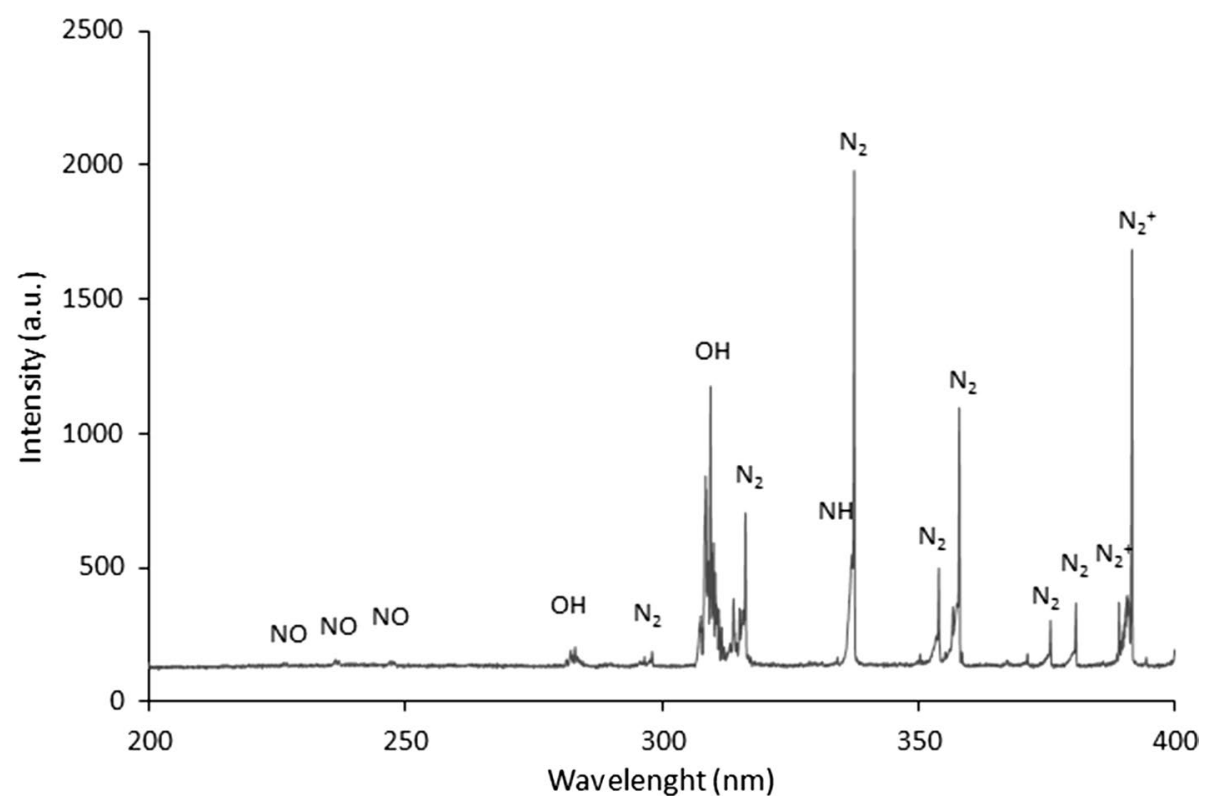

Fig. 2 The emission spectrum of the He-DBD plasma operated under the optimal conditions

emission bands of the $N_{2}$ molecules belonging to the $C^{3} \Pi_{u}-B^{3} \Pi_{g}$ system and the emission bands of the $\mathrm{OH}$ radical belonging to the $\mathrm{A}^{2} \Sigma-\mathrm{X}^{2} \Pi$ system. The most intense band heads of the above-mentioned systems were observed for the following transitions: (0-0) in case of $\mathrm{OH}$ at $309.4 \mathrm{~nm}$ as well as (1-0), (0-0) and (0-1) in case of $\mathrm{N}_{2}$ at $315.9 \mathrm{~nm}, 337.1 \mathrm{~nm}$ and $357.7 \mathrm{~nm}$, respectively. Additionally, few other emission bands were identified, including the (0-0), (0-1), and (0-2) transitions for the NO molecules with the band heads at $226.9 \mathrm{~nm}, 237.0 \mathrm{~nm}$, and $247.9 \mathrm{~nm}$, respectively, belonging to the $\gamma$-system $\left(\mathrm{A}^{2} \Sigma^{+}-\mathrm{X}^{2} \Pi\right)$, the $(0-0)$ transition for the $\mathrm{NH}\left(\mathrm{A}^{3} \Pi-\mathrm{X}^{3} \Sigma^{-}\right)$system with the band head at $336.0 \mathrm{~nm}$, as well as the (0-0), and (0-1) transitions for the $\mathrm{N}_{2}^{+}$molecules with the band heads at $391.4 \mathrm{~nm}$ and $427.8 \mathrm{~nm}$, respectively, belonging to the $\mathrm{B}^{2} \Sigma_{\mathrm{u}}^{+}-X^{2} \Sigma_{\mathrm{g}}^{+}$system. The O I lines at $777.2 \mathrm{~nm}$ and $844.6 \mathrm{~nm}$ with the excitation energy $\sim 11 \mathrm{eV}$, and the $\mathrm{H}$ lines of the Balmer series at $486.1 \mathrm{~nm}$, and $656.2 \mathrm{~nm}$ with the excitation energies within $12-13 \mathrm{eV}$ were also observed. It should be noted that the most prominent He I lines were not identified in the spectra of the examined He-DBD plasma, probably due to the high excitation threshold energy levels of the He atoms, i.e., $\sim 22-23 \mathrm{eV}$.

Since it was found that $\mathrm{N}_{2}, \mathrm{~N}_{2}^{+}$, NO, and $\mathrm{OH}$ were the predominant reactive species produced in the gaseous phase of He-DBD, the selected ROS and RNS were likely to be produced in the liquid phase treated by the He-DBD plasma as a result of the plasma-liquid interactions. Hence, the concentrations of the $\mathrm{H}_{2} \mathrm{O}_{2}$ molecules, and the $\mathrm{NO}_{2}^{-}$ions, in addition to the $\mathrm{pH}$ were determined in the $0.85 \%(\mathrm{~m} / \mathrm{v}) \mathrm{NaCl}$ solutions treated by He-DBD under optimal conditions. Although the subsequent treatment of the human skin cell lines with He-DBD was performed only for $90 \mathrm{~s}$ (see below), the treatment times of 300, 600, and $1200 \mathrm{~s}$ were used in this examination due to the technical constraints. It was established that the concentrations of all three measured species increased with the increased He-DBD treatment time (Fig. 3). The correlation between the concentration of the $\mathrm{H}_{2} \mathrm{O}_{2}$ molecules and the He-DBD operation time might be associated with the $\mathrm{H}_{2} \mathrm{O}$ oxidative processes, 
Fig. 3 The $\mathrm{H}_{2} \mathrm{O}_{2}$ and $\mathrm{NO}_{2}^{-}$ concentration along with $\mathrm{pH}$ of a $0.85 \%(\mathrm{~m} / \mathrm{v}) \mathrm{NaCl}$ solution following the 300-, 600-, and 1200-s He-DBD treatment

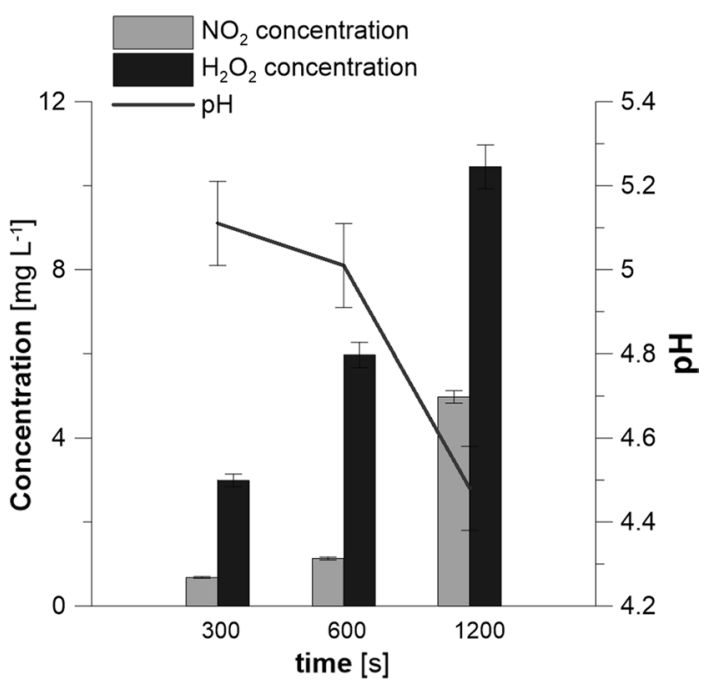

as was suggested by Locke et al. [62]. In the case of the $\mathrm{NO}_{2}^{-}$ions, their fabrication in the He-DBD-treated solution was possibly associated with the synthesis of the $\mathrm{HNO}_{2}$ molecules [52]. The decreasing $\mathrm{pH}$ might be related to the irradiation of the solutions with the positive ions, e.g., $\mathrm{H}_{2} \mathrm{O}^{+}$, as was suggested previously by Tochikubo et al, [63] Our results, hence, were in line with those of other studies that also reported the increase in the concentrations of the studied reactive species following the CAPP treatment [15, 64].

\section{Evaluation of the Effect of the Portable He-DBD-Based Reaction-Discharge System on the Wound Healing}

The effect of the He-DBD plasma on the wound healing was examined using the developed portable reaction-discharge system operated under the optimal conditions. The treatment of the normal human skin cell lines with He-DBD for 0 and $90 \mathrm{~s}$ was found to be non-toxic. The longer treatment lengths were established to induce a strong cytotoxic effect (data not shown). Therefore, all the functional tests presented in this study were performed with the studied cells that were treated with He-DBD for 0-90 s.

Figure 4 shows the augmentation of the proliferation of the HSkMEC. 2 cells activated with He-DBD for $10 \mathrm{~s}$, the MSU-1.1 cells activated with He-DBD for $60 \mathrm{~s}$ and the HaCaT
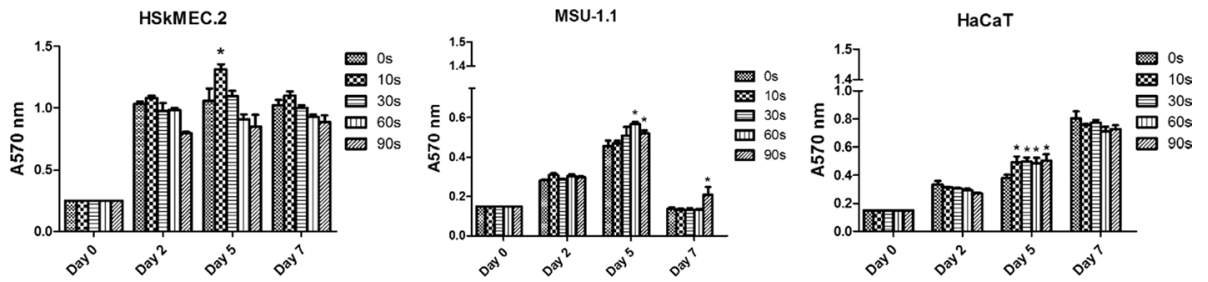

Fig. 4 The proliferation of the skin endothelial cells (HSkMEC.2), fibroblasts (MSU-1.1), and keratinocytes $(\mathrm{HaCaT})$ treated with the He-DBD plasma sustained in the developed reaction-discharge system for 10-90 s from 0 to 7 days. As a control, the cells not treated with He-DBD (0 s) were used. Data are presented as mean \pm SD of three analyses done in triplicate. The statistical comparison was performed using the MannWhitney test $\left({ }^{*} p<0.05\right)$ 
cells activated for 10-90 s on Day 5 as compared to the untreated cells (no He-DBD activation). These results showed that He-DBD might stimulate the proliferation of the normal human skin cells, which are involved in the wound healing process. Similar results were obtained by other research groups, who observed the increased proliferation of the cells treated with He-DBD over the short time periods [17, 65]. In comparison to the epidermal keratinocytes and dermal fibroblasts, which are relatively robust towards the CAPP treatments, our results showed that the endothelial cells were more sensitive to the direct He-DBD treatment. Longer than $10 \mathrm{~s}$ time plasma exposure reduced skin endothelial cells proliferation and may be unfavorable for their angiogenic activity. Moreover, in this study for the first time has been documented proliferation of human non-malignant endothelial cells of skin-origin treated with CAPP.

For proper wound closure, migration of cells involved in wound healing is necessary. In vitro cell migration was assessed by scratch test and proved heightened migratory potential of skin vessel endothelial cells, keratinocytes, and fibroblasts treated with HeDBD compared to control (Fig. 5). Similar results were obtained in previously published papers where keratinocytes and fibroblasts were used [66, 67]. In our study the in vitro tests were extended and combine all population of skin-derived cells such as keratinocytes, fibroblasts, and endothelial cells to assess their motility after direct He-DBD treatment. There was a significant increase in cell motility and scratch area closure for short treatment times $(10 \mathrm{~s})$ in all cell lines. Obtained results approves that He-DBD treatment might also influence the wound healing process by accelerating migration ability of skin-origin cells involved in regenerative effect in the wound site.

Proper wound revascularization has beneficial effect to accelerate wound healing. Pseudo-vessel tube formation in vitro was induced when the cells were treated with HeDBD for $30 \mathrm{~s}$ compared to the untreated control $(0 \mathrm{~s})$, whereas the HSkMEC. 2 cells formed reduced numbers of tubes after $60 \mathrm{~s}$ of the He-DBD treatment and did not form any vascular sprouts after the 90-s exposure to He-DBD (Fig. 6).

All the results were in accordance with the observations published by Arndt and coworkers showing that the exposure of the human endothelial cells to the plasma for the short periods stimulated their angiogenesis [68]. For that reason, the developed portable He-DBD-based reaction-discharge system might be an interesting and viable alternative to other CAPP-based devices described so far in the literature, distinguishing due to its simplicity and versatility. Thus, in vitro studies documented that short-term CAPP treatment
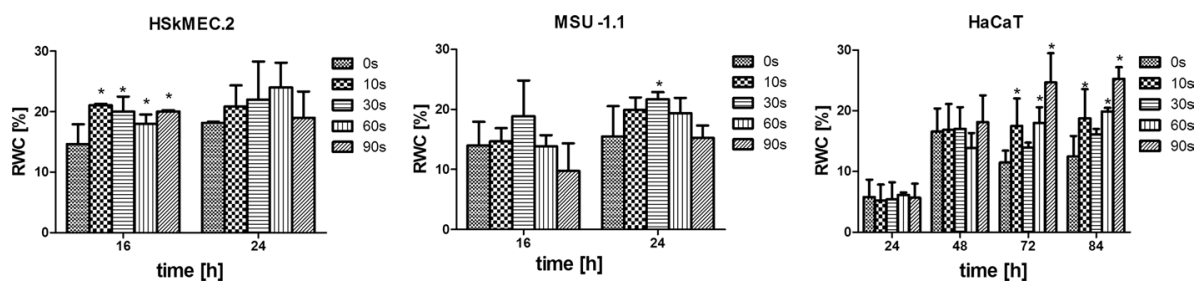

Fig. 5 The scratch assays with the skin endothelial cells (HSkMEC.2), the fibroblasts (MSU-1.1), and the keratinocytes (HaCaT) were performed to monitor the artificial in vitro wound healing. All cell types were grown to confluence after the exposure to He-DBD (0-90 s). Subsequently, the monolayers were scratched, and the rate of the migration was measured after 16 and $24 \mathrm{~h}$, or 24, 48, 72, and $84 \mathrm{~h}$ by quantifying the relative wound closure (RWC \%). There was a significant increase in the cell motility for the short treatment times in all cell lines. Data are presented as mean \pm SD of three analyses done in triplicate. Statistical analysis was performed using Mann-Whitney test and comparison to untreated controls $(* p<0.05)$ 

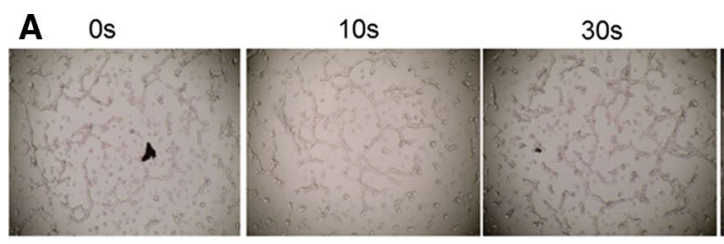

60 s 90 s
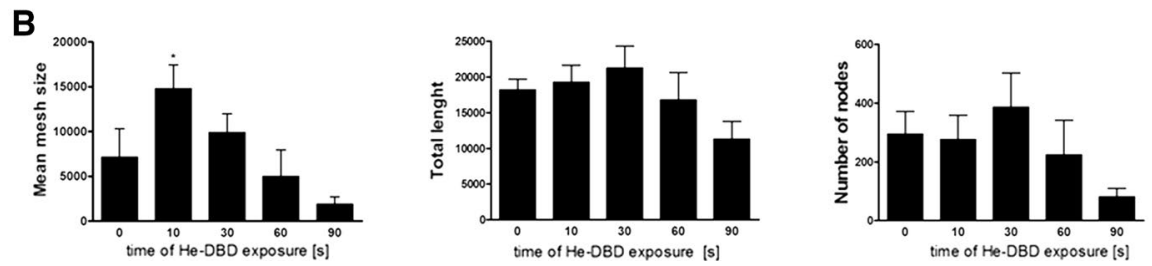

Fig. 6 The tube formation by the human endothelial skin cells (HSkMEC.2) after the direct He-DBD treatment. The HSkMEC. 2 cells were directly treated with He-DBD for $0,10,30,60$, or $90 \mathrm{~s}$ and the number of tubes was determined using the Matrigel ${ }^{\circledR}$ tube formation assay after $6 \mathrm{~h}$. a The images showing the tube formation by the HSkMEC.2 cells after various times of He-DBD treatment $\mathbf{b}$ the evaluated mean mesh size, the total length, and the number of nodes of the HSkMEC.2 cells as determined by the ImageJ software. Data are presented as mean \pm SD of three analyses done in duplicate. Statistical analysis was performed using Mann-Whitney test and comparison to untreated controls $\left({ }^{*} p<0.05\right)$

(10 s) improve keratinocytes and fibroblasts migration, enhanced pro-angiogenic activities and accelerate closure of gaps in scratch test. This observation suggests that He-DBD treatment may be applied in vivo to enhance cutaneous wound healing.

\section{Conclusions}

As a remedy to the high demand for new, fast, and efficient therapies related to the activation of the skin cells responsible for the wound healing, the portable and safe He-DBD-based reaction-discharge system was developed and dedicated to the activation of the normal human skin cells. Because of the variety of the operating parameters that might affect the gas temperature, the DoE followed by the RSM were applied to reliably find the optimal conditions under which the gas temperature in the developed portable He-DBD-based reaction-discharge system would be close to $37{ }^{\circ} \mathrm{C}(310 \mathrm{~K})$. Using this multivariate optimization approach it was established and verified that the developed reaction-discharge system should be operated at the frequency of modulation of $2.14 \mathrm{kHz}$, the duty cycle of $74 \%$, and the He flow rate of $10.6 \mathrm{~L} \mathrm{~min}^{-1}$. The examination of the reactive species formed in the gaseous phase of He-DBD as well as in the He-DBD-treated liquid was performed in order to find out which reactive forms were produced during the CAPP operation. It was shown that our portable He-DBD-based reaction-discharge system successfully stimulated the skin cell (including keratinocytes, fibroblasts, and endothelial cells) proliferation and migration, as well as the angiogenesis of the endothelial cells. It was observed that by changing the He-DBD treatment time, the biological effect could be varied. In addition, it is worth noting that the results of the present work on the optimization of the developed He-DBD-based reaction-discharge system for the activation of the normal human skin cells are competitive to the well-described and studied atmospheric pressure plasma jets. Future studies must reveal 
which reactive species produced during the CAPP operation are finally responsible for the determined activation of the skin cells biology and the CAPP treatment in the in vivo model.

Acknowledgements This work was financed by the Polish Ministry of Science and Higher Education for the Faculty of Chemistry of Wroclaw University of Science and Technology and by Wroclaw Centre of Biotechnology, the program Leading National Research Centre (KNOW) for years 2014-2018. In addition, it was financed by the statutory activity subsidy from the Polish Ministry of Science and Higher Education for the Faculty of Chemistry of Wroclaw University of Science and Technology. A. D. is supported by the Foundation for Polish Science (FNP), program START 022.2018 and by the Polish Ministry of Science and Higher Education (UMO-532/STYP/13/2018), program Outstanding Young Scientist. A. D. is also grateful to the French Embassy for the BGF scholarship dedicated to the international collaboration. Authors would like to thank Dr. George diCenzo for providing graphical support and proofreading the following manuscript.

Open Access This article is distributed under the terms of the Creative Commons Attribution 4.0 International License (http://creativecommons.org/licenses/by/4.0/), which permits unrestricted use, distribution, and reproduction in any medium, provided you give appropriate credit to the original author(s) and the source, provide a link to the Creative Commons license, and indicate if changes were made.

\section{References}

1. Frykberg RG, Banks J (2015) Challenges in the treatment of chronic wounds. Adv Wound Care 4:560-582

2. Peterson JW (1996) Bacterial pathogenesis. In: Baron S (ed) Medical microbiology. University of Texas Medical Branch, Galveston

3. Giacometti A, Cirioni O, Schimizzi AM, Del Prete MS, Barchiesi F, D'errico MM, Petrelli E, Scalise G (2000) Epidemiology and microbiology of surgical wounds infections. J Clin Microbiol 38:918-922

4. Leekha S, Terrell CL, Edson RS (2011) General principles of antimicrobial therapy. Mayo Clinic Proc 86:156-167

5. Hartwig S, Doll C, Voss JO, Hertel M, Preissner S, Raguse JD (2017) Treatment of wound healing disorders of radial forearm free flap donor sites using cold atmospheric plasma: a proof of concept. J Oral Maxillofac Surg 75:429-435

6. Garcia-Alcantara E, Lopez-Callejas R, Morales-Ramirez PR, Pena-Eguiluz R, Fajardo-Munoz R, Mercado-Cabrera A, Baracio SR, Valencia-Alvarado R, Rodriguez-Mendez BG, Munoz-Castra AE, de la Piedad-Beneitez A, Rojas-Olmedo IA (2013) Accelerated mice skin acute wound healing in vivo by combined treatment of argon and helium plasma needle. Arch Med Res 44:169-177

7. Haertel B, von Woedtke T, Weltmann KD, Lindequist U (2014) Non-thermal atmospheric-pressure plasma possible application in wound healing. Biomol Ther 22:477-490

8. Haertel B, Eiden K, Deuter A, Wende K, von Woedtke T, Lindequist U (2014) Differential effect of non-thermal atmospheric pressure plasma on angiogenesis. Lett Appl NanoBioSci 3:159-166

9. Reuter S, von Woedtke T, Weltmann KD (2018) The kINPen - a review on physics and chemistry of the atmospheric pressure plasma jet and its applications. J Phys D Appl Phys 51:233001

10. Ulrich C, Kluschke F, Patzelt A, Vandersee S, Czaika VA, Richter H, Bob A, von Hutten J, Painsi C, Huge R, Kramer A, Assadian O, Lademann J, Lange-Asschenfeldt B (2015) Clinical use of cold atmospheric pressure argon plasma in chronic leg ulcers: a pilot study. J Wound Care 24:196-200

11. Isbary G, Morfill G, Schmidt HU, Georgi M, Ramrath K, Heinlin J, Karrer S, Landthaler M, Shimizu T, Steffers B, Bunk W, Monetti R, Zimmermann JL, Pompl R, Stolz W (2010) A first prospective randomized controlled trial to decrease bacterial load using cold atmospheric argon plasma on chronic wounds in patients. Br J Dermatol 163:78-82

12. Assadian O, Ousey KJ, Daeschlein G, Kramer A, Parker C, Tanner J, Leaper DJ (2019) Effects and safety of atmospheric low-temperature plasma on bacterial reduction in chronic wounds and wound size reduction: a systematic review and meta-analysis. Int Wound J 16:103-111

13. Kang SK, Kim HY, Yun GS, Lee JK (2105) Portable microwave air plasma device for wound healing. Plasma Sources Sci Technol 24:035020 
14. Brehmer F, Haenssle HA, Daeschlein G, Ahmed R, Pfeiffer S, Gorlitz A, Simon D, Schon MP, Wandke D, Emmer S (2015) Alleviation of chronic venous leg ulcers with a hand-held dielectric barrier discharge plasma generator (PlasmaDerm $\left({ }^{\circledR}\right)$ VU-2010): results of a monocentric, two-armed, open, prospective, randomized and controlled trial (NCT01415622). J Eur Acad Deramtol Venereol 29:148-155

15. Arjunan KP, Friedman G, Fridman A, Clyne AM (2012) Non-thermal dielectric barrier discharge plasma induces angiogenesis through reactive oxygen species. J R Soc Interface 9:147-157

16. Zhang JP, Guo L, Chen QL, Zhang KY, Wang T, An GZ, Zhang ZF, Li HP, Ding GR (2019) Effects and mechanisms of cold atmospheric plasma on skin wound healing of rats. Contrib Plasma Phys 59:92-101

17. Hasse S, Duong Tran T, Hahn P, Kindler S, Metelamann HR, von Woedtke T, Masur K (2016) Induction of proliferation of basal epidermal keratinocytes by cold atmospheric-pressure plasma. Clin Exp Dermatol 41:202-209

18. Bekeschus S, Schmidt A, Weltmann KD, von Woedtke T (2016) The plasma jet kINPen-a powerful tool for wound healing. Clin Plasma Med 4:19-28

19. Chen Q, Li J, Li Y (2015) A review of plasma-liquid interactions for nanomaterial synthesis. J Phys D Appl Phys 48:424005

20. Dzimitrowicz A, Greda K, Lesniewicz T, Jamroz P, Nyk M, Pohl P (2016) Size-controlled synthesis of gold nanoparticles by a novel atmospheric pressure glow discharge system with a metallic pin electrode and a flowing liquid electrode. RSC Adv 6:80773-80783

21. Dzimitrowicz A, Bielawska-Pohl A, diCenzo G, Jamroz P, Macioszczyk J, Klimczak A, Pohl P (2018) Pulse-modulated radio-frequency alternating-current-driven atmospheric-pressure glow discharge for continuous-flow synthesis of silver nanoparticles and evaluation of their cytotoxicity toward human melanoma cells. Nanomaterials 8:398

22. Pawlat J, Starek A, Sujak A, Terebun P, Kwiatkowski M, Budzen M, Andrejko D (2018) Effects of atmospheric pressure plasma jet operating with DBD on Lavatera thuringiaca L. seeds' germination. PloS ONE 13:e0194349

23. Berekzi N, Laroussi M, Konesky G, Roman S (2016) Effects of low temperature plasma on prostate cancer cells using the Bovie Medical J-Plasma ${ }^{\circledR}$ device. Plasma Process Polym 13:1189-1194

24. Lin L, Wang L, Liu Y, Xu C, Tu Y, Zhou J (2018) Non-thermal plasma inhibits tumor growth and proliferation and enhances the sensitivity to radiation in vitro and in vivo. Oncol Rep 40:3405-3415

25. Lu X, Naidis GV, Laroussi M, Reuter S, Graves DB, Ostrikov K (2016) Reactive species in nonequilibrium atmospheric-pressure plasmas: generation, transport, and biological effects. Phys Rep 630:1-84

26. Khlyustova A, Labay C, Machala Z, Ginebra MP, Canal C (2019) Important parameters in plasma jets for the production of RONS in liquids for plasma medicine: a brief review. Front Chem Sci Eng $13: 238-252$

27. Velazquez CO (2007) Angiogenesis and vasculogenesis: inducing the growth of new blood vessels and wound healing by stimulation of bone marrow-derived progenitor cell mobilization and homing. J Vasc Surg 45:A39-A47

28. Kalghatgi S, Friedman G, Fridman A, Clyne AM (2010) Endothelial cell proliferation is enhanced by low dose non-thermal plasma through fibroblast growth factor-2 release. Ann Biomed Eng 38:748-757

29. Brun P, Pathak S, Castagliuolo I, Palu G, Brun P, Zuin M (2014) Helium generated cold plasma finely regulates activation of human fibroblast-like primary cells. PLoS ONE 9:e104397

30. Ngo MHT, Liao JD, Shao PL, Weng CC, Chang CY (2014) Increased fibroblast cell proliferation and migration using atmospheric $\mathrm{N}_{2} / \mathrm{Ar}$ micro-plasma for the stimulated release of fibroblast growth factor-7. Plasma Process Polym 11:80-88

31. Wende K, Landsberg K, Lindequist U, Weltmann KD, von Woedtke T (2010) Using ionized gases and electromagnetic fields special issue — non thermal medical/biological applications distinctive activity of a nonthermal atmospheric-pressure plasma jet on eukaryotic and prokaryotic cells in a cocultivation approach of keratinocytes and microorganisms. IEEE Trans Plasma Sci 38:2479

32. Arndt S, Landthaler M, Zimmermann JL, Unger P, Wacker E, Shimizu T, Li YF, Morfill GE, Bosserhoff AK, Karrer S (2014) Effects of cold atmospheric plasma (CAP) on B-defensins, inflammatory cytokines, and apoptosis-related molecules in keratinocytes in vitro and in vivo. PLoS ONE 10:e0120041

33. Barton A, Wende K, Bundscherer L, Hasse S, Schmidt A, Bekeschus S, Weltmann KD, Lindequist U, Masur K (2013) Non-thermal plasma activates human keratinocytes by stimulation of antioxidant and phase II pathways. Plasma Med 3:125

34. Strassenburg S, Greim U, Bussiahn R, Haertel B, Wende K, von Woedtke T, Lindequist U (2013) Comparison of biological effects on human keratinocytes using different plasma treatment regimes. Plasma Med 3:57 
35. Schmidt A, Wende K, Bekeschus S, Bundscherer L, Barton A, Ottmuller K, Weltmann KD, Masur K (2013) Non-thermal plasma treatment is associated with changes in transcriptome of human epithelial skin cells. Free Radic Res 47:577-592

36. Schmidt A, Dietrich S, Steuer A, Weltmann KD, von Woedtke T, Masur K, Wende K (2015) Nonthermal plasma activates human keratinocytes by stimulation of antioxidant and phase II pathways. J Biol Chem 290:6731-6750

37. Nasir NM, Lee BK, Yap SS, Thong KL, Yap SL (2016) Cold plasma inactivation of chronic wound bacteria. Arch Biochem Biophys 605:76-85

38. Golda J, Held J, Redeker B, Konkowski M, Beijer P, Sobota A, Kroesen G, Braithwaite NStJ, Reuter S, Turner MM, Gans TM, Connell DO, der Schulz-von G (2016) Concepts and characteristics of the 'COST Reference Microplasma Jet'. J Phys D Appl Phys 49:084003

39. Gorbanev Y, Verlackt CCW, Tinck S, Tuenter E, Foubert K, Cos P, Bogaerts A (2018) Combining experimental and modelling approaches to study the sources of reactive species induced in water by the COST RF plasma jet. Phys Chem Chem Phys 20:2797-2808

40. Rad ZS, Davani FA, Etaati G (2018) Determination of proper treatment time for in vivo blood coagulation and wound healing application by non-thermal helium plasma jet. Aust Phys Eng Sci Med 41:905-917

41. Gidon D, Curtis B, Paulson JA, Graves DB, Mesbah A (2017) Model-based feedback control of a kHz-excited atmospheric pressure plasma jet. IEEE Trans Rad Plasma Med Sci 2:129-137

42. Gidon D, Graves DB, Mesbah A (2017) Effective dose delivery in atmospheric pressure plasma jets for plasma medicine: a model predictive control approach. Plasma Sources Sci Technol 26:085005

43. Darmawati S, Rohmani A, Nurani LH, Prastiyanto ME, Dewi SS, Salsabila N et al (2019) When plasma jet is effective for chronic wound bacteria inactivation, is it also effective for wound healing? Clin Plasma Med 14:100085

44. Cheng KY, Lin ZH, Cheng YP, Chiu HY, Yeh NL, Wu TK, Wu JS (2018) Wound healing in streptozotocin-induced diabetic rats using atmospheric-pressure argon plasma jet. Sci Rep 8:12214

45. Busco G, Omran AV, Ridou L, Pouvesle JM, Robert E, Grillon C (2019) Cold atmospheric plasmainduced acidification of tissue surface: visualization and quantification using agarose gel models. J Phys D Appl Phys 52:24LT01

46. Swiderski K, Dzimitrowicz A, Jamroz P, Pohl P (2018) Influence of pH and low-molecular weight organic compounds in solution on selected spectroscopic and analytical parameters of flowing liquid anode atmospheric pressure glow discharge (FLA-APGD) for the optical emission spectrometric (OES) determination of Ag, Cd, and Pb. J Anal At Spectrom 33:437-451

47. Dzimitrowicz A, Lesniewicz T, Greda K, Jamroz P, Nyk M, Pohl P (2015) Production of gold nanoparticles using atmospheric pressure glow microdischarge generated in contact with a flowing liquid cathode - a design of experiments study. RSC Adv 5:90534-90541

48. Montgomery DC, Kowalski SM (2012) Minitab manual design and analysis of experiments, 8th edn. American Society for Quality Press, Milwaukee

49. Motyka A, Dzimitrowicz A, Jamroz P, Lojkowska E, Sledz W, Pohl P (2018) Rapid eradication of bacterial phytopathogens by atmospheric pressure glow discharge generated in contact with a flowing liquid cathode. Biotechnol Bioeng 115:1581-1593

50. Jamroz P, Greda K, Pohl P (2014) Direct current atmospheric pressure microdischarge generated between a miniature flow helium microjet and a flowing liquid cathode. Plasma Process Polym 11:755-762

51. Hoskova S, Nemcova I (1990) A spectrophotometric study of the reaction of nitrite with rivanol: determination of nitrite and nitrate in mixtures. Microchem J 41:296-301

52. Jamroz P, Greda K, Pohl P, Zyrnicki W (2014) Atmospheric pressure glow discharges generated in contact with flowing liquid cathode: production of active species and application in wastewater purification processes. Plasma Chem Plasma Process 34:25-37

53. Boukamp P, Petrussevska RT, Breitkreutz D, Hornung J, Markham A, Fusenig NE (1988) Normal keratinization in a spontaneously immortalized aneuploid human keratinocyte cell line. J Cell Biol 106:761-771

54. Hurlin PJ, Maher VM, McCormick JJ (1989) Malignant transformation of human fibroblasts caused by expression of a transfected T24 HRAS oncogene. Proc Natl Acad Sci USA 86:187-191

55. Kieda C, Paprocka M, Krawczenko A, Zalecki P, Dupuis P, Monsigny M, Radzikowski C, Dus D (2002) New human microvascular endothelial cell lines with specific adhesion molecules phenotypes. Endothelium 9:247-261

56. Henklewska M, Pawlak A, Kutkowska J, Pruchnik H, Rapak A, Obminska-Mrukowicz B (2019) In vitro effects of the activity of novel platinum (II) complex in canine and human cell lines. Vet Comp Oncol. https://doi.org/10.1111/vco.12511 
57. Beyeler J, Schnyder I, Katsaros C, Chiquet M (2014) Accelerated wound closure in vitro by fibroblasts from a subgroup of cleft lip/palate patients: role of transforming growth factor- $\alpha$. PLoS ONE 9:e111752

58. Bursac Z, Gauss CH, Williams DK, Hosmer DW (2008) Purposeful selection of variables in logistic regression. Source Code Biol Med 3:17

59. Horvatic V, Vadla C, Franzke J (2014) Discussion of fundamental processes in dielectric barrier discharges used for soft ionization. Spectrochim Acta B 100:52-61

60. Jamroz P, Zyrnicki W, Pohl P (2012) The effect of a miniature argon flow rate on the spectral characteristics of a direct current atmospheric pressure glow micro-discharge between an argon microjet and a small sized flowing liquid cathode. Spectrochim Acta B 73:26-34

61. Chan GCY, Shelley JT, Jackson AU, Wiley JS, Engelhard C, Graham Cook R, Hieftje GM (2011) Spectroscopic plasma diagnostics on a low-temperature plasma probe for ambient mass spectrometry. J Anal At Spectrom 26:1434-1444

62. Locke BR, Shih KY (2011) Review of the methods to form hydrogen peroxide in electrical discharge plasma with liquid water. Plasma Sources Sci Technol 20:034006

63. Tochikubo F, Yudai S, Shirai N, Uchida S (2014) Chemical reactions in liquid induced by atmospheric-pressure de glow discharge in contact with liquid. Jpn J Appl Phys 53:12601

64. Busco G, Fasani F, Dozias S, Ridou L, Douat C, Pouvesle JM, Robert E, Grillon C (2018) Changes in Oxygen Level Upon Cold Plasma Treatments: consequences for RONS Production. IEEE Trans Radiat Plasma Med Sci 2:147

65. Shi XM, Xu GM, Zhang GJ, Liu JR, Wu JM, Gao LG, Yang Y, Chang ZS, Yao CW (2018) Low-temperature plasma promotes fibroblast proliferation in wound healing by ROS-activated NF- $\mathrm{BB}$ signaling pathway. Curr Med Sci 38:107-114

66. Schmidt A, Bekeschus S, Wende K, Vollmar B, von Woedtke T (2017) A cold plasma jet accelerates wound healing in a murine model of full-thickness skin wounds. Exp Dermatol 26:156-162

67. Choi JH, Song YS, Song K, Lee HJ, Hong JW, Kim GC (2017) Skin renewal activity of non-thermal plasma through the activation of $\beta$-catenin in keratinocytes. Sci Rep 7:6146

68. Arndt S, Unger P, Berneburg M, Bosserhoff AK, Karrer S (2018) Cold atmospheric plasma (CAP) activates angiogenesis-related molecules in skin keratinocytes, fibroblasts and endothelial cells and improves wound angiogenesis in an autocrine and paracrine mode. J Dermatol Sci 89:181

Publisher's Note Springer Nature remains neutral with regard to jurisdictional claims in published maps and institutional affiliations.

\section{Affiliations}

Anna Dzimitrowicz ${ }^{1} \cdot$ Aleksandra Bielawska-Pohl $^{2} \cdot$ Piotr Jamroz $^{1} \cdot$ Jerzy Dora $^{3}$. Agnieszka Krawczenko ${ }^{2}$. Giovanni Busco ${ }^{4}$. Catherine Grillon ${ }^{4}$. Claudine Kieda ${ }^{5}$. Aleksandra Klimczak ${ }^{2} \cdot$ Dominik Terefinko $^{1,2} \cdot$ Aleksandra Baszczynska $^{1} \cdot$ Pawel Pohl $^{1}$

Anna Dzimitrowicz

anna.dzimitrowicz@pwr.edu.pl

$\triangle$ Aleksandra Bielawska-Pohl

aleksandra.bielawska-pohl@hirszfeld.pl

1 Department of Analytical Chemistry and Chemical Metallurgy, Faculty of Chemistry, Wroclaw University of Science and Technology, Wybrzeze St. Wyspianskiego 27, 50-370 Wrocław, Poland

2 Laboratory of Biology of Stem and Neoplastic Cells, Hirszfeld Institute of Immunology and Experimental Therapy, Polish Academy of Science, R. Weigla 12, 53-114 Wrocław, Poland

3 Dora Electronics Equipment, Wilczycka 8, 51-512 Wrocław, Poland

4 Centre for Molecular Biophysics, UPR4301, CNRS, 45071 Orléans, France

5 Laboratory of Molecular Oncology, Military Institute of Medicine, Szaserow 128, 04-141 Warsaw, Poland 